LINGUA, Vol. 17, No. 1, Maret 2020

p ISSN: 1979 9411; e ISSN: 2442 238X

Https://soloclcs.org; Email: presslingua@gmail.com

Center of Language and Cultural Studies, Surakarta, Indonesia

Bakri, Fahriatin, Baiq; Mahyudi, Johan \& Mahsun. (2020). Perempuan di Bidang Politik dalam Surat Kabar Lompok Post Tahun 2019: Analisis Wacana Kritis Perspektif Teun V. Van Dijk. Lingua (2020), 17(1):65 78. DOI: 10.30957/lingua.v17i1.625.

\title{
Perempuan di Bidang Politik dalam Surat Kabar Lombok Post Tahun 2019: Analisis Wacana Kritis Perspektif Teun A. Van Dijk
}

\author{
Baiq Fahriatin Bakri' ${ }^{1}$ Johan Mahyudi ${ }^{2}$ \& Mahsun ${ }^{3}$ \\ Magister Pendidikan Bahasa Indonesia Universitas Mataram \\ Jalan Majapahit No. 62 Kota Mataram Nusa Tenggara Barat
}

Corresponding author: ${ }^{1}$ baigfahriatin15@gmail.com

2mahyudi@unram.ac.id \& ${ }^{3}$ mahsunirn@gmail.com

\begin{abstract}
This study focuses on the analysis of critical discourse on micro structure, superstructure, and macro structure in women's text in the political field in the Lombok Post newspaper in 2019. The theory used in this study is the theory of critical discourse analysis according to Teun A. van Dijk on the text dimension which consists of micro structures related to linguistic aspects consisting of semantic, syntactic, stylistic, and rhetorical elements. Superstructures related to the structure of the text or the text scheme. Macro structure related to the theme in general. This research is a qualitative research. Data collection methods in this study use the method of literature, which is a method that can help researchers in collecting data and filtering data that will be used for research. Data analysis method in this research uses data analysis method according to Miles and Huberman. The results of this study show how the text analysis of news texts about women in politics in the Lombok Post newspaper in 2019 is based on van Dijk's discourse analysis theory.
\end{abstract}

Keywords: women, politics, newspapers, van Dijk's critical discourse analysis

\section{PENDAHULUAN}

Pemberitaan tentang perempuan dan kesetaraan gender merupakan dua hal yang tidak dapat dipisahkan. Keduanya sering menjadi topik dalam media maupun pada acara diskusi-diskusi tertentu. Meskipun pada zaman modern seperti sekarang dan sudah lama kita mengenal istilah emansipasi wanita, namun topik perempuan dan kesetaraan gender masih hangat untuk diperbincangkan. Perempuan sering dikategorikan sebagai sosok manusia nomor dua setelah kaum laki-laki. Perempuan di sini artinya tidak bisa memiliki kedudukan yang sejajar dengan kaum laki-laki dalam beberapa aspek tertentu, salah satunya untuk ikut dalam dunia politik.

Budaya patriarki menempatkan perempuan pada sektor domestik atau berada di dalam rumah, terlebih lagi bagi perempuan yang sudah menikah. Sedangkan, kaum lakilaki masih dianggap sebagai tokoh utama yang berperan dalam rumah tangga sebagai pencari nafkah dan mempunyai ambisi untuk menguasai. Perempuan yang sudah menikah sering dikatakan memiliki tanggung jawab penuh di rumah mengurus anak dan 
LINGUA, Vol. 17, No. 1, Maret 2020

p ISSN: 1979 9411; e ISSN: 2442 238X

Https://soloclcs.org; Email: presslingua@gmail.com

Center of Language and Cultural Studies, Surakarta, Indonesia

Bakri, Fahriatin, Baiq; Mahyudi, Johan \& Mahsun. (2020). Perempuan di Bidang Politik dalam Surat Kabar Lompok Post Tahun 2019: Analisis Wacana Kritis Perspektif Teun V. Van Dijk. Lingua (2020), 17(1):65 78. DOI: 10.30957/lingua.v17i1.625.

tugas rumah tangga lainnya. Jika mereka ikut terjun sebagai wanita karir dikhawatirkan akan mengesampingkan tugas mereka sebagai ibu rumah tangga.

Kekhawatiran itu menjadi dilema bagi setiap perempuan yang sudah menikah untuk ikut berkecimpung dalam sektor publik. Mereka juga mempunyai hak yang sama dengan laki-laki dan ingin mensejajarkan dirinya dengan laki-laki. Peran perempuan dalam sektor publik dapat memberikan pengaruh yang positif dalam berbagai hal, misalnya perempuan ikut berperan dalam dunia politik. Keikutsertaan mereka dapat menjadi jalan untuk memperjuangkan suara dan menampung aspirasi kaum wanita lain di luar sana.

Pemberitaan tentang perempuan yang ikut serta dalam dunia politik sudah banyak dipublikasikan dalam berbagai media, salah satunya surat kabar. Surat kabar Lombok Post merupakan salah satu surat kabar di NTB yang memberitakan tentang perempuan yang ikut berkecimpung dalam dunia politik. Oleh karena itu, menarik untuk dikaji bagaimana surat kabar Lombok Post yang merupakan surat kabar terbesar di NTB dalam memberitakan perempuan dalam dunia politik. Dalam penelitian ini objek penelitian akan dipersempit pada teks-teks tentang perempuan yang duduk di kursi dewan pada tahun 2019 dengan menggunakan analisis wacana model Teun A. van Dijk.

\section{Rumusan Masalah}

Sesuai dengan latar belakaang di atas, penelitian ini membuat tiga rumusan masalah sebagai berikut.

1) Bagaimanakah perempuan di bidang politik dalam surat kabar Lombok Post tahun 2019 pada struktur mikro menurut van Dijk?

2) Bagaimanakah perempuan di bidang politik dalam surat kabar Lombok Post tahun 2019 pada superstruktur menurut van Dijk?

3) Bagaimanakah perempuan di bidang politik dalam surat kabar Lombok Post tahun 2019 pada struktur makro menurut van Dijk?

\section{KAJIAN TEORI}

Analisis wacana model van Djik adalah model yang paling banyak digunakan. Hal ini kemungkinan karena van Djik mengelaborasi elemen-elemen wacana sehingga bisa didayagunakan dan dipakai secara praktis. Menurut van Djik (dalam Eriyanto, 2012:221), penelitian atas wacana tidak cukup hanya didasarkan pada analisis atas teks semata karena teks hanya hasil dari suatu praktek produksi yang harus juga diamati. Di sini harus dilihat juga bagaimana suatu teks diproduksi, sehingga kita memperoleh suatu pengetahuan kenapa teks bisa semacam itu. Analisis wacana kritis menurut Van Dijk disajikan pada gambar 1 . 
LINGUA, Vol. 17, No. 1, Maret 2020

p ISSN: 1979 9411; e ISSN: 2442 238X

Https://soloclcs.org; Email: presslingua@gmail.com

Center of Language and Cultural Studies, Surakarta, Indonesia

Bakri, Fahriatin, Baiq; Mahyudi, Johan \& Mahsun. (2020). Perempuan di Bidang Politik dalam Surat Kabar Lompok Post Tahun 2019: Analisis Wacana Kritis Perspektif Teun V. Van Dijk. Lingua (2020), 17(1):65 78. DOI: 10.30957/lingua.v17i1.625.

Gambar 1. Model Analisis Wacana Kritis Teun A. van Dijk

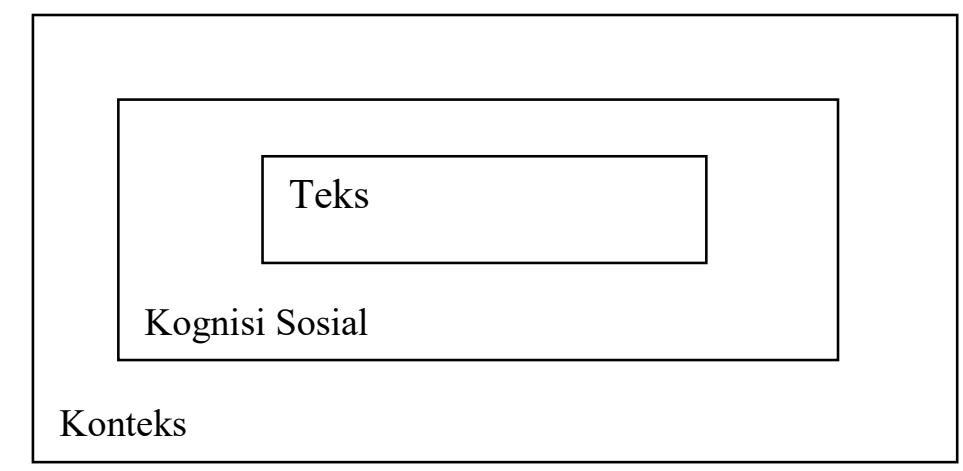

(Eriyanto,2012:223)

Wacana oleh van Dijk digambarkan mempunyai tiga dimensi/bangunan, yakni teks, kognisi sosial, dan konteks sosial (Eriyanto, 2012:224). Inti analisis van Dijk adalah menggabungkan ketiga dimensi wacana tersebut ke dalam satu kesatuan analisis. Dalam dimensi teks, yang diteliti adalah bagaimana struktur teks dan strategi wacana yang dipakai untuk menegaskan suatu tema tertentu. Pada level kognisi sosial dipelajari proses produksi berita yang melibatkan kognisi individu dari wartawan. Sedangkan aspek ketiga mempelajari bangunan wacana yang berkembang dalam masyarakat akan suatu masalah. Analisis van Dijk menghubungkan analisis tekstual yang memusatkan perhatian pada teks ke arah analisis yang komprehensif bagaimana teks berita itu diproduksi, baik dalam hubungannya dengan individu wartawan maupun dari masyarakat.

Van Dijk melihat suatu teks terdiri atas beberapa struktur/tingkatan yang masing-masing bagian saling mendukung. Ia membaginya ke dalam tiga tingkatan, yakni struktur makro, superstruktur, dan struktur mikro. Lihat gambar 2.

Gambar 2. Struktur Teks Menurut Teun A. van Dijk

\begin{tabular}{|c|}
\hline $\begin{array}{c}\text { Struktur Makro } \\
\text { Makna global dari suatu teks yang dapat diamati dari topik/tema yang diangkat oleh } \\
\text { suatu teks. }\end{array}$ \\
$\begin{array}{c}\text { Superstruktur } \\
\text { Kerangka suatu teks,seperti bagian pendahuluan, isi, penutup, dan kesimpulan. }\end{array}$ \\
\hline $\begin{array}{c}\text { Struktur Mikro } \\
\text { Makna lokal dari suatu teks yang dapat diamati dari pilihan kata, } \\
\text { kalimat dan gaya yang dipakai oleh suatu teks. }\end{array}$ \\
\hline
\end{tabular}

(Eriyanto, 2012:227)

Pemakaian kata, kalimat, proposisi, retorika tertentu oleh media dipahami van Dijk sebagai bagian dari strategi wartawan. Pemakaian kata-kata tertentu, kalimat, gaya tertentu bukan semata-mata dipandang sebagai cara berkomunikasi tetapi dipandang 
LINGUA, Vol. 17, No. 1, Maret 2020

p ISSN: 1979 9411; e ISSN: 2442 238X

Https://soloclcs.org; Email: presslingua@gmail.com

Center of Language and Cultural Studies, Surakarta, Indonesia

Bakri, Fahriatin, Baiq; Mahyudi, Johan \& Mahsun. (2020). Perempuan di Bidang Politik dalam Surat Kabar Lompok Post Tahun 2019: Analisis Wacana Kritis Perspektif Teun V. Van Dijk. Lingua (2020), 17(1):65 78. DOI: 10.30957/lingua.v17i1.625.

sebagai politik berkomunikasi, yakni suatu cara untuk mempengaruhi pendapat umum, menciptakan dukungan, memperkuat legitimasi, dan menyingkirkan lawan atau penentang. Struktur wacana adalah cara yang efektif untuk melihat proses retorika dan persuasi yang dijalankan ketika seseorang menyampaikan pesan. Kata-kata tertentu mungkin dipilih untuk mempertegas pilihan dan sikap, membentuk kesadaran politik, dan sebagainya.

\section{a. Struktur Mikro}

Struktur mikro merupakan analisis sebuah teks berdasarkan unsur-unsur intrinsiknya. Unsur-unsur tersebut meliputi: (a) Unsur semantik yang dalam hal ini dikategorikan sebagai makna lokal, yakni makna yang muncul dari hubungan antarkalimat, hubungan antarproposisi yang membangun makna tertentu dalam suatu bangunan teks. Analisis wacana banyak memusatkan perhatian pada dimensi teks seperti makna yang eksplisit ataupun implisit, makna yang sengaja disembunyikan dan bagaimana orang menulis dan berbicara mengenai hal itu. Dengan kata lain, semantik tidak hanya mendefinisikan bagian mana yang penting dari struktur wacana, tetapi juga menggiring ke arah sisi tertentu dari suatu peristiwa (Sobur, 2015:78). (b) Unsur sintaksis merupakan salah satu elemen yang membantu pembuat teks untuk memanipulasi keadaan dengan jalan penekanan secara tematik pada tatanan kalimat. Manipulasi tersebut dapat berupa pemilihan penggunaan kata, kata ganti, preposisi, dan konjungsi, serta pemilihan bentuk-bentuk kalimat seperti kalimat pasif atau aktif, (c) unsur stilistik menurut Geoffrey Leech dalam buku (Critical Theory) Teun A. van DijkDiscourse and Literature_New Approaches to the Analysis of Literary Genres-John Benjamins Publishing Company (1985) mengatakan bahwa, stylistics is the study of style; of how language use varies according to varying circumstances. Stilistik adalah studi tentang gaya bahasa yang mempelajari bagaimana penggunaan bahasa yang bervariasi sesuai dengan keadaan yang berbeda-beda. Terkait dengan gaya bahasanya, sebuah teks bisa menampilkan style melalui diksi atau pilihan kata, pilihan kalimat, majas atau ciri kebahasaan lainnya, (d) unsur retoris merupakan unsur gaya penekanan sebuah topik dalam sebuah teks dengan cara pengulangan, penghapusan, penggantian,dan lain-lain. Gaya penekanan ini berhubungan erat dengan bagaimana pesan sebuah teks akan disampaikan, yang meliputi gaya metafora, perbandingan, ironi, atau gaya bahasa lainnya (van Dijk, 1998;208).

\section{1) Unsur Semantik}

a) Latar

Latar merupakan bagian berita yang dapat mempengaruhi semantik (arti) yang ingin ditampilkan. Seorang wartawan ketika menulis berita biasanya mengemukakan latar belakang atas peristiwa yang ditulis. Latar yang dipilih menentukan ke arah mana pandangan khalayak hendak dibawa. Latar umumnya ditampilkan di awal sebelum pendapat wartawan yang sebenarnya muncul dengan maksud mempengaruhi dan memberi kesan bahwa pendapat wartawan sangat beralasan (Eriyanto, 2012:235). Oleh 
LINGUA, Vol. 17, No. 1, Maret 2020

p ISSN: 1979 9411; e ISSN: 2442 238X

Https://soloclcs.org; Email: presslingua@gmail.com

Center of Language and Cultural Studies, Surakarta, Indonesia

Bakri, Fahriatin, Baiq; Mahyudi, Johan \& Mahsun. (2020). Perempuan di Bidang Politik dalam Surat Kabar Lompok Post Tahun 2019: Analisis Wacana Kritis Perspektif Teun V. Van Dijk.

Lingua (2020), 17(1):65 78. DOI: 10.30957/lingua.v17i1.625.

karena itu, latar membantu menyelidiki bagaimana seseorang memberi pemaknaan (pro atau kontra) atas suatu peristiwa.

\section{b) Detail}

Elemen wacana detail berhubungan dengan kontrol informasi yang ditampilkan oleh seseorang. Komunikator akan menampilkan secara berlebihan informasi yang menguntungkan dirinya atau citra yang baik. Sebaliknya, ia akan menampilkan informasi dalam jumlah sedikit (bahkan kalau perlu tidak disampaikan) kalau hal itu merugikan kedudukannya. Informasi yang menguntungkan komunikator, bukan hanya ditampilkan secara berlebih tetapi juga dengan detail yang lengkap kalau perlu dengan data-data. Detail yang lengkap dan panjang lebar merupakan penonjolan yang dilakukan secara sengaja untuk menciptakan citra tertentu kepada khalayak (Eriyanto, 2012:238).

\section{c) Maksud}

Elemen wacana maksud hampir sama dengan elemen detail. Dalam detail, informasi yang menguntungkan komunikator akan diuraikan dengan detail yang panjang. Elemen maksud melihat informasi yang menguntungkan komunikator akan diuraikan secara eksplisit dan jelas. Sebaliknya, informasi yang merugikan akan diuraikan secara tersamar, implisit, dan tersembunyi. Tujuan akhirnya adalah publik hanya disajikan informasi yang menguntungkan komunikator (Eriyanto, 2012:240). Elemen maksud dalam konteks media bertujuan untuk menunjukkan bagaimana secara implisit dan tersembunyi wartawan menggunakan praktek bahasa tertentu untuk menonjolkan basis kebenarannya dan secara implisit pula menyingkirkan versi kebenaran lain.

\section{d) Praanggapan}

Praanggapan adalah upaya mendukung pendapat dengan memberikan premis yang dipercaya kebenarannya. Praanggapan hadir dengan pernyataan yang dipandang terpercaya sehingga tidak perlu dipertanyakan (Eriyanto, 2012:256). Teks berita umumnya mengandung banyak praanggapan, namun belum terbukti kebenarannya dan dijadikan sebagai dasar untuk mendukung gagasan tertentu. Jadi, praanggapan merupakan sebuah argumen yang diberikan oleh media meski kenyataannya belum terjadi tetapi didasarkan pada sebuah anggapan.

\section{2) Unsur Sintaksis}

\section{a) Bentuk Kalimat}

Bentuk kalimat adalah segi sintaksis yang berhubungan dengan cara berpikir logis, yaitu prinsip kausalitas. Bentuk kalimat ini menentukan apakah subjek diekspresikan secara eksplisit atau implisit dalam teks. Kalimat aktif umumnya digunakan agar seseorang menjadi subjek dari tanggapannya, sebaliknya kalimat pasif menempatkan seseorang sebagai objek (Eriyanto, 2012:251).

Bentuk kalimat ini ditandai dengan pemakaian urutan kata-kata yang mempunyai dua fungsi sekaligus, yakni meletakkan proposisi di awal kalimat (deduktif) 
LINGUA, Vol. 17, No. 1, Maret 2020

p ISSN: 1979 9411; e ISSN: 2442 238X

Https://soloclcs.org; Email: presslingua@gmail.com

Center of Language and Cultural Studies, Surakarta, Indonesia

Bakri, Fahriatin, Baiq; Mahyudi, Johan \& Mahsun. (2020). Perempuan di Bidang Politik dalam Surat Kabar Lompok Post Tahun 2019: Analisis Wacana Kritis Perspektif Teun V. Van Dijk. Lingua (2020), 17(1):65 78. DOI: 10.30957/lingua.v17i1.625.

dan di akhir kalimat (induktif). Penempatan tersebut dapat mempengaruhi makna yang timbul karena akan menunjukkan bagian mana yang lebih ditonjolkan kepada khalayak. Bentuk kalimat deduktif aspek penonjolannya lebih kentara, sementara dalam bentuk induktif inti dari kalimat ditempatkan tersamar atau tersembunyi. Bentuk kalimat pada analisis wacana terkait dengan penggunaan kalimat aktif atau kalimat pasif dan kalimat deduktif atau kalimat induktif.

\section{b) Koherensi}

Koherensi merupakan salah satu aspek wacana yang penting dalam menunjang keutuhan makna wacana. Bila suatu ujaran tidak memiiki koherensi, hubungan semantik-pragmatik yang seharusnya menjadi tidak terbina dan tidak logis. Brown dan Yule (dalam Mulyana, 2005:135) menegaskan bahwa keherensi berarti kepaduan dan keterpahaman antarsatuan dalam suatu teks dan tuturan. Dalam struktur wacana, aspek koherensi sangat diperlukan keberadaannya untuk menata pertalian batin antara proposisi yang satu dengan lainnya untuk mendapat keutuhan makna.

Koherensi secara mudah dapat diamati di antaranya dari kata hubung (konjungsi) yang dipakai untuk menghubungkan fakta, seperti hubungan kausal (sebab akibat), hubungan keadaan, waktu, kondisi, dan sebagainya. Misalnya pernyataan, "lima mahasiswa Trisakti tewas akibat bentrok dengan aparat keamanan". Di sini ada dua kalimat, yaitu "mahasiswa yang tewas" dan "mahasiswa bentrok dengan aparat keamanan". Kedua kalimat itu dihubungkan dengan sebagai sebab akibat. Menggunakan kata hubung yang lain akan memberikan makna yang berbeda. Tujuan pemakaian aspek koherensi ini antara lain adalah agar tercipta suasana dan struktur wacana yang memiliki sifat serasi, runtut, dan logis.

Koherensi dibagi menjadi dua, yakni koherensi kondisional (penjelas) dan koherensi pembeda. Koherensi kondisional di antaranya ditandai dengan pemakaian anak kalimat sebagai penjelas. Kalimat penjelas biasanya adalah kalimat kedua dari proposisi pertama yang dihubungkan dengan konjungsi. Kalimat kedua tersebut fungsinya dalam kalimat semata hanya penjelas (anak kalimat), sehingga ada atau tidak ada anak kalimat itu tidak akan mengurangi arti kalimat (Eriyanto, 2012:244). Koherensi pembeda berhubungan dengan pertanyaan bagaimana dua peristiwa atau fakta itu hendak dibedakan. Dua buah peristiwa dapat dibuat seolah-olah saling bertentangan dan berseberangan dengan menggunakan koherensi ini (Eriyanto, 2012:247). Efek pemakaian koherensi pembeda ini bermacam-macam. Akan tetapi, yang terlihat nyata adalah bagaimana pemaknaan yang diterima oleh khalayak berbeda karena satu fakta atau realitas dibandingkan dengan realitas lain. Secara umum, koherensi ini dapat dengan mudah diamati dilihat dari kata hubung yang digunakan untuk menghubungkan fakta atau proposisi.

\section{c) Kata Ganti}

Kata ganti merupakan elemen untuk memanipulasi bahasa dengan menciptakan suatu komunitas imajinatif. Kata ganti merupakan alat yang dipakai oleh komunikator untuk menunjukkan di mana posisi seseorang dalam wacana (Eriyanto, 2012:253). Kata 
LINGUA, Vol. 17, No. 1, Maret 2020

p ISSN: 1979 9411; e ISSN: 2442 238X

Https://soloclcs.org; Email: presslingua@gmail.com

Center of Language and Cultural Studies, Surakarta, Indonesia

Bakri, Fahriatin, Baiq; Mahyudi, Johan \& Mahsun. (2020). Perempuan di Bidang Politik dalam Surat Kabar Lompok Post Tahun 2019: Analisis Wacana Kritis Perspektif Teun V. Van Dijk. Lingua (2020), 17(1):65 78. DOI: 10.30957/lingua.v17i1.625.

ganti "saya" atau "kami" digunakan untuk menggambarkan bahwa sikap tersebut merupakan sikap resmi komunikator. Akan tetapi, ketika menggunakan kata ganti "kita" menjadikan sikap tersebut sebagai representasi dari sikap bersama dalam suatu komunitas. Apa yang menjadi sikap wartawan seolah-olah juga menjadi sikap khalayak. jadi, penggunaan kata ganti sangat mempengaruhi posisi seseorang dalam sebuah wacana.

\section{3) Unsur Stilistik}

Pada unsur stilitistik hanya akan membahas leksikon dalam teks. Elemen leksikon menandakan bagaimana seseorang melakukan pemilihan kata atas berbagai kemungkinan kata yang tersedia (Eriyanto, 2012:255). Pilihan kata yang dipakai tidak semata hanya karena kebetulan tetapi juga secara ideologis menunjukkan bagaimana pemaknaan seseorang terhadap fakta/realitas. Oleh karena itu, pemilihan kata yang berbeda akan memberikan makna yang berbeda pula kepada pembaca.

\section{4) Unsur Retoris \\ a) Grafis}

Elemen ini merupakan bagian untuk memeriksa apa yang ditekankan atau ditonjolkan oleh seseorang yang dapat diamati dari teks. Grafis biasanya muncul dalam wacana berita lewat bagian tulisan yang dibuat lain dibandingkan tulisan lain (Eriyanto, 2012:257). Pemakaian huruf tebal, huruf miring, pemakaian garis bawah, huruf yang dibuat dengan ukuran lebih besar. Pemakaian caption, raster, grafik, gambar, atau tabel untuk mendukung arti penting suatu pesan. Bagian-bagian yang ditonjolkan ini menekankan kepada khalayak pentingnya bagian tersebut. Pemakaian angka-angka dalam berita di antaranya digunakan untuk mensugestikan kebenaran, ketelitian, dan posisi dari suatu laporan. Berbagai macam ukuran tulisan dalam berita surat kabar memiliki maksud dan tujuan tertentu.

Elemen grafis terkait dengan bagian tulisan yang dibuat berbeda dengan tulisan yang lainnya, penggunaan gambar, grafik, tabel bertujuan untuk memberikan penekanan kepada khalayak bahwa bagian tersebut penting.

\section{b) Metafora}

Dalam suatu wacana, seorang wartawan tidak hanya menyampaikan pesan pokok lewat suatu teks, tetapi juga kiasan, ungkapan, metafora yang dimaksud sebagai ornamen atau bumbu dari suatu berita sebagai landasan berpikir dan alasan pembenar atas pendapat atau gagasan tertentu kepada publik. Metafora juga bisa menjadi petunjuk utama untuk mengerti makna suatu teks (Eriyanto, 2012:259). Gaya bahasa yang digunakan tidak terbatas hanya menggunakan metafora saja, melainkan juga menggunakan beberapa gaya bahasa yang lain, seperti ironi, perbandingan, dan lainlain. Penggunaan berbagai jenis gaya bahasa tersebut bertujuan untuk memberikan penekanan terhadap sebuah topik dalam suatu teks. 
LINGUA, Vol. 17, No. 1, Maret 2020

p ISSN: 1979 9411; e ISSN: 2442 238X

Https://soloclcs.org; Email: presslingua@gmail.com

Center of Language and Cultural Studies, Surakarta, Indonesia

Bakri, Fahriatin, Baiq; Mahyudi, Johan \& Mahsun. (2020). Perempuan di Bidang Politik dalam Surat Kabar Lompok Post Tahun 2019: Analisis Wacana Kritis Perspektif Teun V. Van Dijk. Lingua (2020), 17(1):65 78. DOI: 10.30957/lingua.v17i1.625.

\section{c). Superstruktur}

Superstruktur memiliki satu elemen, yakni elemen skematik. Teks atau wacana umumnya mempunyai skema atau alur dari pendahuluan sampai akhir. Alur tersebut menunjukkan bagaimana bagian-bagian dalam teks disusun dan diurutkan sehingga membentuk kesatuan arti. Wacana pengetahuan seperti jurnal atau tulisan ilmiah juga mempunyai skematik.

Meskipun mempunyai bentuk dan skema yang beragam, berita umumnya secara hipotetik mempunyai dua kategori skema besar. Pertama, summary yang umumnya ditandai dengan dua elemen yang dipandang paling penting. Judul dan lead umumnya menunjukkan tema yang ingin dikatakan sebelum masuk dalam isi berita secara lengkap. Menurut Sobur (2015:77) judul berita (head line) pada dasarnya mempunyai tiga fungsi (Anwar, 1996:11), yaitu (a) mengiklankan cerita atau berita, (b) meringkaskan atau mengiktisarkan cerita, dan (3) memperbagus halaman surat kabar. Dalam judul berita tidak diizinkan mencantumkan sesuatu yang berifat pendapat atau opini. Sama halnya dengan judul berita, lead juga mempunyai beberapa fungsi. Lead adalah intisari berita yang mempunyai tiga fungsi, yakni (a) menjawab rumus $5 \mathrm{~W}+1 \mathrm{H}$ (who, what, where, when, why, how), (b) menekankan newsfeature of the story dengan menempatkan pada posisi awal, dan (c) memberikan identifikasi cepat tentang orang, tempat, dan kejadian yang dibutuhkan bagi pemahaman cepat berita itu.

Kedua, story yakni isi berita secara keseluruhan. Isi berita ini secara hipotetik juga mempunyai dua subkategori. Pertama berupa situasi, yakni proses atau jalannya peristiwa dan yang kedua, komentar yang ditampilkan dalam teks. Menurut Sobur (2015:77-78) situasi menggambarkan kisah suatu peristiwa umumnya terdiri dari dua bagian. Yang pertama mengenai episode atau kisah utama dari peristiwa tersebut dan yeng kedua latar untuk mendukung episode yang disajikan kepada khalayak. latar umumnya dipakai untuk memberi konteks agar suatu peristiwa lebih jelas ketika disampaikan kepada khalayak. sedangkan, komentar adalah bagian yang menggambarkan bagaimana pihak-pihak yang terlibat memberikan komentar atas suatu peristiwa secara hipotetik terdiri atasdua bagian. Pertama, reaksi atau komentar verbal dari tokoh yang dikutip oleh wartawan. Kedua kesimpulan yang diambil oleh wartawan dari komentar berbagai tokoh.

\section{d). Struktur Makro}

Struktur makro menunjuk pada makna keseluruhan (global meaning) yang dapat dicermati dari tema atau topik yang diangkat oleh suatu wacana (Eriyanto, 2012:227). Dengan kata lain, analisis struktur makro merupakan analisis sebuah teks yang dipadukan dengan kondisi sosial di sekitarnya untuk memperoleh satu tema sentral. Tema sebuah teks tidak terlihat secara eksplisit di dalam teks, melainkan tercakup di dalam keseluruhan teks secara satu kesatuan bentuk yang koheren.

Struktur makro memiliki satu elemen, yakni tematik. Elemen tematik menunjuk pada gambaran umum dari suatu teks. Bisa juga disebut sebagai gagasan inti, ringkasan, atau yang utama dari suatu teks. Topik menggambarkan apa yang ingin diungkapkan 
LINGUA, Vol. 17, No. 1, Maret 2020

p ISSN: 1979 9411; e ISSN: 2442 238X

Https://soloclcs.org; Email: presslingua@gmail.com

Center of Language and Cultural Studies, Surakarta, Indonesia

Bakri, Fahriatin, Baiq; Mahyudi, Johan \& Mahsun. (2020). Perempuan di Bidang Politik dalam Surat Kabar Lompok Post Tahun 2019: Analisis Wacana Kritis Perspektif Teun V. Van Dijk. Lingua (2020), 17(1):65 78. DOI: 10.30957/lingua.v17i1.625.

oleh wartawan dalam pemberitaannya. Topik menunjukkan konsep dominan, sentral, dan paling penting dari isi suatu berita (Eriyanto, 2012:230).

\section{METODE}

Penelitian ini dilakukan dengan menggunakan metode penelitian kualitatif yang berupa metode analisis wacana kritis. Metode kualitatif adalah prosedur penelitian yang menghasilkan data deskriptif, yaitu ucapan atau tulisan, atau perilaku yang dapat diamati dari subjek itu sendiri (Fuchran, 1998:11). Analisis wacana berita dalam penelitian ini dilakukan dengan cara menginterpretasi atau menafsirkan teks-teks yang ada pada surat kabar Lombok Post tentang perempuan di bidang politik.

Metode pengumpulan data pada penelitian ini menggunakan metode kepustakaan. Menurut Nazir (2011:63) dalam bukunya yang berjudul 'Metode Penelitian", metode kepustakaan merupakan metode pengumpulan data dengan melakukan studi penelaahan terhadap buku-buku, literatur-literatur, catatan-catatan, dan laporan-laporan yang ada hubungannya dengan masalah yang akan dipecahkan.

Proses kedua dalam penelitian ini adalah analisis data. Pada tahapan analisis data, data yang sudah dikelompokkan selanjutnya dianalisis dengan teknik analisis wacana. Teknik analisis data disesuaikan dengan kebutuhan penelitian dan permasalahan penelitian ini (Badara, 2019:72). Penelitian ini akan dianalisis berdasarkan teori analisis wacana kritis model Teun A. van Dijk. Data-data tersebut dianalisis berdasarkan elemen-elemen yang dikembangkan oleh van Dijk yang pertama yakni, dimensi teks yang terdiri dari struktur makro yang mencakup tema atau topik, superstruktur yang mencakup skema atau kerangka penulisan teks, dan struktur mikro yang mencakup unsur semantik (latar, detail, maksud, dan pranggapan), unsur sintaksis (bentuk kalimat, koherensi, dan kata ganti), unsur stilistik (leksikon), dan unsur retoris (grafis, metafora).

Analisis data dalam penelitian ini menggunakan metode analisis data menurut Milles and Huberman. Analisis data pada penelitian kualitatif dilakukan sebelum penelitian, selama penelitian, dan sesudah penelitian. Berikut langkah-langkah dalam menganalisis data menurut Milles and Huberman.

\section{a. Pengumpulan Data}

Tahap awal dalam penelitian kualitatif adalah mengumpulkan data. Mengumpulkan data memerlukan waktu berminggu-minggu bahkan berbulan-bulan. Data yang akan dikumpulkan pada penelitian ini terkait dengan teks tentang perempuan di bidang politik dalam surat kabar Lombok Post tahun 2019.

\section{b. Reduksi Data}

Pada tahap reduksi data, data yang telah dikumpulkan kemudian dirangkum dan pilih data-data pokok terkait dengan penelitian yakni data struktur mikro yang berkaitan dengan aspek kebahasaan, superstruktur yang berkaitan dengan skema, dan struktur makro yang berkaitan dengan makna teks perempuan di bidang politik dalam surat kabar Lombok Post tahun 2019. 
LINGUA, Vol. 17, No. 1, Maret 2020

p ISSN: 1979 9411; e ISSN: 2442 238X

Https://soloclcs.org; Email: presslingua@gmail.com

Center of Language and Cultural Studies, Surakarta, Indonesia

Bakri, Fahriatin, Baiq; Mahyudi, Johan \& Mahsun. (2020). Perempuan di Bidang Politik dalam Surat Kabar Lompok Post Tahun 2019: Analisis Wacana Kritis Perspektif Teun V. Van Dijk. Lingua (2020), 17(1):65 78. DOI: 10.30957/lingua.v17i1.625.

\section{c. Penyajian Data}

Setelah mereduksi data, maka langkah selanjutnya adalah menyajikan data. Penyajian data pada penelitian kualitatif bisa dilakukan dalam bentuk uraian singkat, bagan, hubungan antar kategori, dan sejenisnya. Namun, penyajian data pada penelitian kualitatif lebih sering menggunakan teks yang bersifat naratif. Penelitian ini akan menyajikan data menggunakan bagan disertai uraian singkat.

\section{d. Penarikan simpulan dan verifikasi}

Hasil akhir pada penelitian ini dapat menjawab ketiga rumusan masalah yang ada bahwa terdapat analisis struktur mikro, supersturktur, dan struktur makro pada teks perempuan di bidang politik dalam suratkabar Lombok Post tahun 2019.

\section{HASIL DAN PEMBAHASAN}

Berdasarkan data yang diperoleh melalui metode kepustakaan terkait dengan teks perempuan di bidang politik dalam surat kabar Lombok Post tahun 2019, telah ditemukan elemen-elemen pembentuk teks yang sesuai dengan teori analisis wacana kritis Teun A. van Dijk. Hasil yang ditemukan adalah data berupa (1) struktur mikro, (2) superstruktur, dan (3) struktur makro.

Penelitian ini membahas elemen-elemen analisis wacana kritis menurut Teun A. van Dijk. Elemen-elemen tersebut diperoleh berdasarkan wacana yang terdapat pada surat kabar Lombok Post tahun 2019 tentang perempuan di bidang politik. Berikut dipaparkan hasil analisis yang telah dilakukan dalam berita tentang perempuan di bidang politik dengan judul "Sri Muamalah Ajak Masyarakat Peduli Kebersihan".

\subsection{Analisis Struktur Makro}

Analisis pertama adalah analisis struktur mikro. Analisis struktur mikro terdiri dari beberapa analisis, yakni semantik, sintaksis, stilistik, dan retoris. Analisis semantik terdiri dari latar, detail, maksud, dan praanggapan. Latar yang ditampilkan dalam berita tersebut adalah latar yang dipilih oleh wartawan menentukan ke arah mana pandangan pembaca hendak dibawa. Pada berita tersebut, wartawan menggiring pembaca kepada sebuah berita yang menjelaskan tentang kondisi kebersihan Kota Mataram yang sudah membaik. Hal tersebut terdapat pada kutipan berita pada paragraf kedua "penanganan sampah di Kota Mataram sudah mulai membaik". Kemudian wartawan juga menguraikan tentang bagaimana menjaga kebersihan dan mengelola sampah agar menjadi bermanfaat. Hal tersebut terdapat pada kutipan berita keenam, yakni "....sampah plastik dapat dikonversi menjadi bahan bakar dan melibatkan investor atau pihak ketiga yang terkait". Selanjutnya, detail yaitu berhubungan dengan kontrol informasi oleh wartawan. Detail dalam berita tersebut adalah wartawan menguraikan dengan detail yang panjang tentang kebersihan lingkungan yang sudah mulai membaik dan kewajiban semua kalangan untuk menjaga kebersihan lingkungan sekitar serta bagaimana mengelola sampah plastik menjadi bahan bakar. Sedangkan berita tentang penumpukan sampah plastik hanya diuraikan dengan detail yang sedikit. Maksud yakni informasi yang menguntungkan diuraikan secara eksplisit dan jelas, sedangkan 
LINGUA, Vol. 17, No. 1, Maret 2020

p ISSN: 1979 9411; e ISSN: 2442 238X

Https://soloclcs.org; Email: presslingua@gmail.com

Center of Language and Cultural Studies, Surakarta, Indonesia

Bakri, Fahriatin, Baiq; Mahyudi, Johan \& Mahsun. (2020). Perempuan di Bidang Politik dalam Surat Kabar Lompok Post Tahun 2019: Analisis Wacana Kritis Perspektif Teun V. Van Dijk. Lingua (2020), 17(1):65 78. DOI: 10.30957/lingua.v17i1.625.

informasi yang merugikan diuraikan secara implisit dan tersamar. Informasi yang menguntungkan dalam berita ini diuraikan secara eksplisit dan jelas, yakni berita tentang kondisi kebersihan di Kota Mataram yang sudah mulai membaik.

\subsection{Analisis Superstruktur}

Analisis bagian kedua adalah analisis superstruktur. Analisis superstruktur terdiri dari summary (judul dan lead) dan story (situasi dan komentar). Judul berita tersebut adalah Sri Muamalah Ajak Masyarakat Peduli Kebersihan. Lead umumnya terletak pada paragraf pertama. Lead yang terdapat pada berita tersebut adalah masalah kebersihan Kota Mataram yang belum paripurna menjadi sorotan Sri Muamalah, Caleg DPRD Kota Mataram. Warga pagutan ini mengajak masyarakat segala lapisan ikut serta menjaga kebersihan lingkungan. Situasi yang dijelaskan dalam berita tersebut adalah penanganan sampah di Kota Mataram sudah mulai baik. Kepala lingkungan harus mengontrol setiap wilayahnya dan mengajak masyarakat mengelola limbah plastik rumah tangga. Komentar yang diutarakan oleh Sri Muamalah adalah sebagai berikut. (a) "Semua masyarakat harus mendukung program pemerintah, proaktif ikut menata kebersihan Kota Mataram". (b) "Karena sampah plastik ini sulit untuk diurai sehingga perlu penanganan yang maksimal terutama dari rumah tangga". (c) "Gerakan tiga M, yakni menutup, menguras, dan mengubur juga perlu digalakkan".

\subsection{Analisis Struktur Makro: Topik Umum dan Subtopik}

Analisis ketiga yang akan dijabarkan adalah analisis struktur makro yang terdiri dari topik umum dan subtopik. Topik umum dalam berita tersebut adalah caleg Sri Muamalah mengajak seluruh kalangan masyarakat untuk menjaga kebersihan sungai, selokan, dan mengelola sampah plastik untuk mencegah penyakit DBD disaat musim hujan. Subtopik terbagi menjadi beberapa bagian, (a) Caleg Sri Muamalah mengajak menjaga kebersihan. (b) Seluruh kalangan membantu menjaga kebersihan yang sudah mulai membaik. (c) Menjaga kebersihan sungai dan selokan. (d) Menumpuknya sampah plastik. (e) Penanganan sampah rumah tangga. (f) Menjaga kebersihan untuk mencegah penyakit DBD.

\section{SIMPULAN}

Berdasarkan tujuan penelitian yang dilakukan, yakni untuk mengetahui struktur mikro, superstruktur, dan struktur makro tentang teks perempuan di bidang politik dalam surat kabar Lombok Post tahun 2019, maka dapat ditarik sebuah simpulan. Pada penelitian ini ditemukan beberapa struktur pembentuk teks berdasarkan teori yang digunakan, yakni teori analisis wacana kritis Teun A. van Dijk. Beberapa berita yang menjadi data dalam penelitian ini sebagian besar tidak memiliki struktur yang lengkap. Hal ini merupakan keterbatasan dari wartawan ketika menuliskan sebuah berita. Contohnya pada berita yang dibahas di atas, bahwa ada beberapa unsur dalam struktur teks berita yang tidak ditemukan. Unsur pembentuk teks yang sering tidak ditemukan pada data penelitian ini adalah unsur retoris pada bagian metafora. Hal tersebut terjadi 
LINGUA, Vol. 17, No. 1, Maret 2020

p ISSN: 1979 9411; e ISSN: 2442 238X

Https://soloclcs.org; Email: presslingua@gmail.com

Center of Language and Cultural Studies, Surakarta, Indonesia

Bakri, Fahriatin, Baiq; Mahyudi, Johan \& Mahsun. (2020). Perempuan di Bidang Politik dalam Surat

Kabar Lompok Post Tahun 2019: Analisis Wacana Kritis Perspektif Teun V. Van Dijk.

Lingua (2020), 17(1):65 78. DOI: 10.30957/lingua.v17i1.625.

karena penggunaan bahasa oleh wartawan tergolong menggunakan bahasa yang sederhana tanpa adanya bahasa kiasan.

\section{DAFTAR PUSTAKA}

Afdhal, Lalu Muh. Raqib. 2017. Analisis Wacana Kritis Representasi Citra Aparat Penegak Hukum dalam Media Lombok Post. Tesis: Universitas Mataram.

Badara, Aris. 2013. Analisis Wacana: Teori, Metode, dan Penerapannya pada Wacana Media. Jakarta: KENCANA.

Darma, Yoce Aliah. 2013. Analisis Wacana Kritis. Bandung: Yrama Widya.

Depdikbud. 2003. Kamus Besar Bahasa Indonesia. Jakarta: Balai Pustaka.

Eriyanto. 2012. Analisis Wacana Pengantar Analisis Teks Media, cetakan ke-12. Yogyakarta: PT. LKiS Printing Cemerlang.

Fuchran, Arief. 1998. Pengantar Metode Penelitian Kualitatif. Surabaya: PUN.

Hidayat, Imam. 2009. Teori-teori Politik. Malang: Setara Press.

Imam, Ahmad Fachruddien. 2012. Analisis Wacana van Dijk pada Lirik Lagu Irgaa Tani (My Heart Will Go On). Jurnal: Universitas Negeri Semarang.

Muhajir, Muhamad. 2015. Tata Bahasa Sebagai Cerminan Nilai Ideologis Wacana Politik Perempuan dalam "Kolom Perempuan": Kajian Analisis Wacana Kritis Atas Teks Di Harian Suara Merdeka. Jurnal.

Mulia, Siti Musdah. 2007. Islam dan Inspirasi Kesetaraan Gender. Yogyakarta: Kibra Press.

Mushaitir. 2016. Analisis Wacana Kritis Berita Kebijakan Pendidikan dalam Media Cetak Lombok Post dan Relevansinya terhadap Pembelajaran Wacana di Perguruan Tinggi. Tesis: Universitas Mataram.

Nazir. 2011. Metode Penelitian. Jakarta : Ghalia Indonesia.

Prihantoro, Edy. 2018. Stereotip Perempuan Calon Legislatif dalam Wacana Media Massa Online di Tahun Politik. Jurnal Semiotika. Vol.12.(No.1).Hal.16-24. DOI:10.30813/s:jk:v12i1.1540.

Putri, Rini Susanti. 2013. Analisis Wacana Representasi Kasus Korupsi Pejabat dalam Harian Lombok Post dan Relevansinya dengan Pembelajaran Mata Kuliah Analisis Wacana di Perguruan Tinggi. Tesis: Universitas Mataram.

Rista, Intan Zulfiana. 2013. "Analisis Wacana Konstruksi Perempuan di Bidang Politik dalam Majalah Kartini Edisi Khusus 100 Wanita Terinspiratif Tahun 2008-2011 Kategori Politik". Skripsi: Universitas Muhammadiyah Surakarta.

Sobur, Alex. 2015. Analisis Teks Media: Suatu Pengantar untuk Analisis Wacana, Analisis Semiotik, dan Analisis Farming. Bandung: PT. Remaja Rosdakarya.

Subhan, Zaitunah. 2004. Kodrat Perempuan, Takdir, atau Mitos. Jakarta: Lkis. 
LINGUA, Vol. 17, No. 1, Maret 2020

p ISSN: 1979 9411; e ISSN: 2442 238X

Https://soloclcs.org; Email: presslingua@gmail.com

Center of Language and Cultural Studies, Surakarta, Indonesia

Bakri, Fahriatin, Baiq; Mahyudi, Johan \& Mahsun. (2020). Perempuan di Bidang Politik dalam Surat Kabar Lompok Post Tahun 2019: Analisis Wacana Kritis Perspektif Teun V. Van Dijk. Lingua (2020), 17(1):65 78. DOI: 10.30957/lingua.v17i1.625.

van Dijk, Teun. 1998. Ideology: A Multidisciplinary Approach. London: SAGE Publications.

van Dijk, Teun. 1985. Discourse and Literature_New Approaches to the Analysis of Literary Genres. Amsterdam: John Benjamins Publishing Company.

Yule, George. 1996. Analisis Wacana. Jakarta: PT. Gramedia Pustaka Utama. 
LINGUA, Vol. 17, No. 1, Maret 2020

p ISSN: 1979 9411; e ISSN: 2442 238X

Https://soloclcs.org; Email: presslingua@gmail.com

Center of Language and Cultural Studies, Surakarta, Indonesia

Bakri, Fahriatin, Baiq; Mahyudi, Johan \& Mahsun. (2020). Perempuan di Bidang Politik dalam Surat Kabar Lompok Post Tahun 2019: Analisis Wacana Kritis Perspektif Teun V. Van Dijk. Lingua (2020), 17(1):65 78. DOI: 10.30957/lingua.v17i1.625. 